\title{
Nationalism, Morality, and Gender: Lorne Pierce and the Canadian Literary Canon, I920-60
}

Sandra Campbell ${ }^{\dagger}$

Lorne Pierce (I890-196I), editor of the Ryerson Press from 1920 to 1960, was arguably Canada's most influential publisher and editor in the period from Canada's coming-of-age after the First World War to the Quiet Revolution. Canadian literary historians have not yet recognized the degree to which Pierce's prescriptive vision of Canadian literature and culture was driven by his nationalism, which was itself in turn influenced by his Methodism and his experiences at Queen's University and in the Canadian West. ${ }^{\mathrm{I}}$ Moreover, on his arrival in Toronto in 1920 from rural Ontario, Pierce's exposure to the cultural nationalism of the Group of Seven sharpened his patriotic desire to publish and promote such poets as Bliss Carman, Sir Charles G.D. Roberts, and Wilson MacDonald, whose landscape poetry seemed to him to give Canadians a literary sense of their landscape in a manner analogous to the canvases of the Group of Seven.

Pierce's literary nationalism - so characteristic of many late nineteenth and twentieth-century English Canadian men of letters - worked in concert with a strong moralism rooted in his Methodism as well as his patriarchal assumptions about gender which, as we will see, were 'in the air' of the Canadian literary world at this time. All three forces - his nationalism, his moralism, and his patriarchal values - influenced his literary work as editor and writer in ways important to the shaping of the Canadian canon and the careers of individual writers published by Ryerson Press in the decades from 1920 to $1960 .^{2}$

Pierce was, of course, not the only important figure in the Canadian publishing world of the 1920 s who espoused a strong literary nationalism. But both his status as editor of the trade division of a

† Sandra Campbell is a member of the Department of English, University of Ottawa, and is writing a biography of Lorne Pierce. Her article is a revised and expanded version of a paper presented at a conference of the Southwestern Association for Canadian Studies at the University of Southwestern Louisiana at Lafayette in February 1993. 
church publishing house and his academic credentials set him apart in crucial ways in the Canadian publishing world of the 1920 . For example, Pierce's contemporaries, Hugh Eayrs (1894-1940), head of the Macmillan Company of Canada from I92I to I940, and John McClelland (1877-1968), the driving force in his own independent firm from 1906 until the 1950s, were also strong literary nationalists. ${ }^{3}$ Unlike Eayrs and McClelland, however, 'Dr. Pierce,' as he was known, was an academically inclined editor whose career involved much more hands-on editorial and critical work than the careers of Eayrs or McClelland. By contrast to Eayrs and McClelland at their respective firms, Pierce, though he enjoyed a large measure of managerial autonomy, was not the administrative head of his firm, and did not do the same amount of administrative work and lobbying in the company of other publishers on issues like copyright and tariffs. Unlike those of Eayrs and McClelland, the face and name of Lorne Pierce are rarely seen in the accounts of meetings, lobbying, and socializing by publishers found in the trade periodicals of publishing and wholesale bookselling such as Bookseller and Stationer.

Pierce had largely friendly - and at times close - contacts with both Eayrs and McClelland over the years. But his unique position in the Toronto publishing world of his day - that of ordained minister/editor/intellectual who conceptualized and oversaw a large Canadian literary list - was reinforced by a certain 'setapartness.' This apartness was intensified by two factors: his deafness, ${ }^{4}$ and his distaste for the poker-and-liquor socializing of the largely male Toronto literary establishment. Consequently, Pierce, unlike Eayrs and McClelland, concentrated largely on hands-on editorial work in a very different manner and with somewhat different drives than either the sociable, worldly Hugh Eayrs or the pragmatic, business-oriented John McClelland. Pierce functioned as editor/ critic/intellectual/minister in his career as executive of a church publishing house, which was the largest printing and publishing establishment in Canada during this period. ${ }^{5} \mathrm{~A}$ rival publisher jokingly summed up Pierce's unique status in the Canadian publishing world in a magazine interview: 'If all the writers in Canada suddenly dried up . . Ryerson's would be the only house that wouldn't suffer. Why, that Pierce fellow would merely turn out the year's list of books himself. ${ }^{6}$

In June 1920, Pierce had been asked to join Ryerson Press, the newly christened trade division of the ninety-one-year-old Methodist Book and Publishing House, by its general manager, Book Steward S.W. Fallis, who was in search of a clever, cultured, and idealistic 
young Methodist minister to develop the Ryerson book list and book sales in the areas of religious and general publishing. ${ }^{7}$ On 18 June 1920, Pierce, then a young Methodist minister serving in the Eastern Ontario hamlet of Brinston, confided to his diary: 'At 9.10 I sent the wire that sealed my fate and attached me to the [Methodist] Book Room as Literary Critic and Advisor - I think I shall be very happy in it.' A month later, on I I July, his diary entry was filled with zeal and a sense of cultural mission: 'Feel more than ever that I have a real he-man's job, that of making our Meth. Bk. Room the cultural mecca of Canada. ${ }^{8}$

By his own admission, Pierce went to Ryerson with little real knowledge of Canadian literature. 'When I came to the publishing business,' he later told an interviewer, 'I was totally inexperienced in editorial work and in publishing - in addition my own literary interests could scarcely have been less attuned to Canada's own literary needs . . . All my chief interests were non-Canadian. ${ }^{\prime 9}$ During his ministerial training at Victoria College and New York City's Union Theological Seminary, ${ }^{\mathrm{IO}}$ when he had studied literature, he did not for a moment conceive of art for art's sake, but of art as the servant of higher ideals. His thesis on Russian literature for the United Theological College in Montreal in 1922 looked at literature as the national expression of the refining power of suffering. Literature was a means, not an end: it could 'idealise' and 'wrought into gold. ${ }^{\text {II }}$ In 1958, he wrote of his long tenure in the editor's chair to a prospective successor that

It gives you a tremendous forum for your ideas and inspirations, and it extends your mission as an ordained man beyond anything you can imagine...

I have always regarded my self as first of all a minister of the Church, and have imagined my desk to be a sort of altar at which I serve... [as one] very much concerned about the entire cultural life of Canada...

... You would be very happy [in my job]. You would feel that you were a living part of the vast movement of Church and state in Canada, through which we are planning a high destiny for our people. $^{12}$

What Pierce brought to Ryerson was a conviction that literature must be concerned with higher values - morality and patriotism - and that it ought to be a force for national cohesion. These impulses came out of the spiritual emphasis of his stoutly Meth- 
odist upbringing, ${ }^{\mathrm{I} 3}$ and from the idealism and patriotism which he drank in at Queen's University under philosopher John Watson and theologian William Jordan. Work as a Methodist student minister amid a multicultural mosaic on the raw Saskatchewan prairies just before the Great War convinced him that literature had to be a force for patriotic indoctrination and cohesion in a rapidly expanding and diverse economy. What Pierce absorbed from turn-of-the-century Methodism was the spirit of what William Westfall has called 'romantic evangelism,' a dedication to presenting the ideal in words and art, believing it could inspire the individual and exalt society. ${ }^{\mathrm{I}} 4$ His 1925 assessment of 'The National Ideal in Canadian Literature' is firmly in this mould:

... we need three things [in our emerging literature] (I) Utter fidelity to truth; $(2)$ a determination to be ourselves; and $|3|$ a sympathetic atmosphere in which the sublimest beauty, the sweetest music, the loftiest justice and the divinest truth might be expected to take root and flourish, when at last they do appear as ultimately they must and will. ${ }^{\text {Is }}$

Pierce did make Ryerson a cultural mecca. Founded by Egerton Ryerson in 1829, the Methodist Book and Publishing House had been an important force in Canadian literary publishing under Book Steward William Briggs after his appointment in 1879 , but in the decade before Pierce's arrival, the Press had been in the doldrums under the now elderly Briggs. ${ }^{16}$ By contrast, in the years from 1920 until his retirement in 1960, Pierce's vision and energy established the Ryerson Press - as the Methodist Book and Publishing House had rechristened its trade publishing section in 1919 - as a major publisher of Canadian writing. At Pierce's behest as editor, the Ryerson Press published scores of major works of Canadian literature, from E.J. Pratt's Newfoundland Verse (1923) and Frederick Philip Grove's controversial novel Settlers of the March (1925) to Dorothy Livesay's Call My People Home (I947), A.M. Klein's The Rocking Chair and Other Poems (I948), and F.R. Scott's Events and Signals (1954).

Pierce believed that the Ryerson Press must be a force for the growth of Canadian cultural nationhood, a nationhood that linked French and English. As early as I922, he spoke of his belief in the bicultural reality of the nation. The introduction to Our Canadian Literature, an anthology that he co-edited, was emphatic: '[Canadians] have two great shrines at which we speak two languages, yet 
we have but one passionate loyalty - Canada! .. A real history of the literature of Canada must include an appreciation of the history of the French.' ${ }^{17}$ Pierce's interest in French Canada /and the term expresses exactly how he conceptualized the francophone fact in Canada) had first been stirred during his undergraduate years at Queen's before the First World War. ${ }^{18} \mathrm{He}$ conceived of francophone culture and identity as embodying a cohesiveness, spirituality, and national spirit which English Canadians must appreciate and emulate in a parallel fashion. In a booklet entitled Towards the Bonne Entente (1929) Pierce wrote:

We have much to learn from the French [in Canada]. One thing we shall come to understand is, that learning and morals must go hand in hand. If the history of the last twenty-five years means anything, it repudiates and condemns the pride of knowledge without good taste, of scientific inquiry without reverence, of theories about liberty without inhibitions of religious faith, and of hungry ambition with public ethical standards and private morals. It is not to be supposed that our native French literature is a prophylactic for every infection. But one thing is certain, if our teachers and preachers, artists and authors, our people generally west of the Ottawa [River], and south of Gaspe, can sympathetically appreciate the amenities of the hearth, the traditions and customs of the people, the passionate love of the altar, in short, the urbanity, strength and character of the French people, education, literature, art and business will take on a new dignity throughout our land. ${ }^{19}$

Pierce's bicultural nationalism led in the I920s to his pioneering Makers of Canadian Literature series, one of the first attempts at a series of critical works on individual writers which combined biography with a selection and critique of the writer's work. ${ }^{20}$ The series - which Pierce had hoped would run to some thirty-five volumes but which was restricted to thirteen volumes by financial constraints - was the more remarkable in that he included volumes in French on French-Canadian writers, an unusual bicultural initiative at the time. Pierce composed a ringing dedication for the series, typeset in flowing script at the front of each blue-and-gold volume: 'Dedicated to the writers of Canada - past and present the real Master-Builders and Interpreters of our great Dominion in the hope that our People, equal heirs in the rich inheritance, may learn to know them intimately; and knowing them love them; and loving follow.' 
The whiggish zeal of cultural nation-making shaped the series as a critical exercise. For example, a lesser-known writer like Robert Norwood rubbed shoulders in the series with a well-known writer like Charles G.D. Roberts. Pierce's rationale for such pairings is illustrative. Norwood, a Maritimer and poet who in the I920s was a prominent Philadelphia minister and theosophist, had the kind of idealism that Pierce, Roberts, and many others admired. Albert Durrant Watson, author of the inaugural Makers volume on Norwood, was a close friend and father figure to Pierce; he was a physician, a spiritualist, and a theosophical idealist who had urged the aspiring young editor:

Could not the modernists start a revival that would ignore the goose-pastures of the itinerant Evangelist, but get folks to seek the glory of God in the common wholesome things, and make their life and thought watch it in beauty and newness ... ${ }^{2 \mathrm{I}}$

Pierce was intellectually predisposed to agree with such promptings from Watson, his mentor and co-editor for the anthology Our Canadian Literature (1923). He edited the Makers of Canadian Literature series in the light of such urging. This prescriptive thinking meant that the Makers series was to be an exercise in literary nation-building, one replete with a romantic idealism. Accordingly, its critics were urged by Pierce to focus on the heroic brows rather than the feet of clay of the literary pantheon of Makers.

One example will indicate the impact of cultural nation-making on a manuscript. In 1923, Pierce commissioned Sir Andrew Macphail, who ever held an acid pen, to do the Makers volume on Norman Duncan. Macphail - famed and feared for his blunt and controversial opinions - was wary, and before accepting the commission, he asked Pierce: 'Do you want a judgement of his work or mere eulogy, as Watson has done for [the Makers volume on] Norwood. ... Much of Duncan's writing is mere gibberish. ${ }^{22}$ Makers of Canadian Gibberish lacks a nation-building ring, and problems soon arose. On 8 February I924, an agitated Pierce wrote to Macphail:

... after reading your manuscript the question comes up in my own mind, have I not made a mistake in giving Norman Duncan a place at all among THe MAKers of CANADian Literature. A great deal of your criticism, I feel, is quite in order, but it seems to me that the total result of your treatment in both the Biography and Appreciation was too destructive. In most of your criticisms I agree with you; 
but there are many virtues in Duncan, which it seems to me you have overlooked.

Pierce proposed to counterweight the criticism, not demote the Maker:

... I hope that you can see the matter as I do. Here we have an author, granted a MAKER, and yet, upon laying down your book, the unanimous verdict would be that the man ought to be consigned to oblivion. That may be true regarding the majority of his works; but some of his books deserve at least a temporary immortality. Could you not re-cast part of your manuscript, - not to mention the criticism - which criticism is due - but to gather if you can, the salient features of his strength. You may do so in such a way as to still confirm your seasoned opinion that on the whole, his virtues are overshadowed by his faults; but as it stands now, whatever mention you make of his virtue is so embedded in the fiercest kind of criticism, that the whole work defeats our purpose. ${ }^{23}$

Unusually for him, Macphail did relent. He did not turn to 'booming' Duncan by any means: an examination of the two drafts of the Duncan manuscript in the Macphail papers at the National Archives of Canada establishes that, as Pierce had suggested, he softened but did not eliminate his strictures on Duncan to produce a more balanced, less trenchant assessment. ${ }^{24}$ Macphail told Pierce in February I924: 'The book is now exactly as you want it to be. I have written an introduction in praise of the stories you reprint. I have mitigated all criticism without sophisticating the truth.'25 However, the 'temporary immortality' that Pierce had negotiated for Duncan proved to be temporary indeed. In the end, the series was halted by the financial costs of the venture before the Duncan volume could appear.

Another important manifestation of Pierce's cultural nationalism has too long been overlooked by Canadian scholars. Pierce's credo that the 'publisher must remain one of the chief forces that make a conscious and sustained effort to enrich and preserve the cultural and spiritual values in our heritage ${ }^{26}$ led Ryerson to produce elementary and high school textbooks which included material from the country's literature and history. Like any publisher, Pierce was interested in capturing the lucrative textbook market, but he also wanted to inculcate patriotic feeling with basic education. $\mathrm{He}$ wrote in I939: 
I do not see how we can have a nation at all, let alone native art and literature - still the best index of our social energy - without a rediscovery of the imponderables [in education]. We lack significant goals for our striving, and a solid core of meaning, and loyalty to it, to hold us together on our way. ${ }^{27}$

As a result, with Pierce as 'hands-on' editor-in-chief, and in conjunction with Macmillan of Canada, Ryerson initiated work in 1929 on a series of basic readers - The Treasury Readers for Grades I to vi, followed by The Canada Books of Prose and Verse for Grades vir to xIr. These hugely successful readers, in a variety of titles and editions, became widely used texts in elementary schools and high schools in much of English Canada over the next thirty-five years. (By I96I, the textbooks for grades VII to XII had a combined national sale of 200,000 copies per year. ${ }^{28}$ ) In addition to excerpts from Shakespeare, Wordsworth and other classics, for example, Grade viI students who studied The Canada Book of Prose and Verse, Book II, were exposed to the work of fifteen Canadian writers, including Bliss Carman's 'Songs of the Sea Children' and Stephen Leacock's 'My Financial Career.'

These were the first Canadian readers with systematic and extensive Canadian literary content, and they had an important role in fixing recognition of Canadian writing in the minds of elementary and high school students. Were the seeds of the Canadian literary boom of the I96os planted by the Readers of the I930s, I940s, and I950s? It is an interesting question, and certainly Pierce believed that he was indoctrinating and building a literary audience through these texts. In a more immediate and practical manner, the large profits from these textbooks made possible Ryerson's Canadian literary publishing: by Pierce's own admission, Ryerson lost money on virtually every volume of poetry it published, making him seem a 'lyrical wild man' in the eyes of the House accountants. ${ }^{29}$

Pierce's nationalist, cultural endeavours were not limited to the printed word. For Pierce, Canadian art - the work of C.W. Jefferys, of the Group of Seven and their contemporaries in particular - had intensified his own patriotism in the I920s: exposure to such art was, therefore, an important element in appreciating 'the spirit of Canada.' ${ }^{\circ}$ As a result, he had The Ryerson Canadian History Readers, an inspirational, whiggish series of dozens of booklets on heroes and events from Canadian history from Jacques Cartier to The Story of Hydro, illustrated by the Canadian artist C.W. Jefferys (I869-I95I). Jefferys's stirring depiction of scenes from Canadian 
history, conceived in close consultation with Pierce, became visual icons for generations of Canadian students, an artistic nationalism which culminated in Jefferys's best-selling Picture Gallery of Canadian History, published in three volumes by the Ryerson Press between 1942 and 1950. Under Pierce, Ryerson made works on Canadian art and artists a continuing part of their catalogue with a landmark series of monographs on Canadian artists (J.E.H. MacDonald, Cornelius Krieghoff, Tom Thomson/ which began in the I 930 . Ironically, the series was made possible by Christmas cards. In 1937, Rous and Mann Ltd., which did art printing for Ryerson, acquired a sophisticated colour press and a collection of Canadian art plates to produce Christmas cards. The printing firm told Pierce that illustrations for the series of booklets on Canadian art, which Pierce had long discussed with them, had now become feasible. ${ }^{3 \mathrm{I}}$

Pierce's idealism affected the Ryerson list in other concrete ways. He had the Methodist unease about fiction and distaste for what he perceived as amorality in art. Early in his editorial career he urged ministers to avoid much of current fiction or else 'sin wilfully,' as 'there is no philosophy of life there that will bear scrutiny. ${ }^{\prime 2}$ His puritanical disdain for Margot Asquith's candid diary permeated his I920 review of the work for his regular book review column in the Methodist Christian Guardian. He equated her revelations with female immodesty:

Her whole performance has as much justification as dressing in the street. It is a practice which, if made universal, would be disastrous, a letting down the bars that defies every canon of good taste and good breeding. ... [The book is] a crowning illustration of the ultimate abomination to which verbal and ethical desolation may descend. ${ }^{33}$

Not surprisingly, the Ryerson fiction list was never as strong as the poetry list, even after Pierce instituted the Ryerson Fiction Award in 1942. True, he braved public disapproval - and almost lost his job - by publishing Grove's Settlers of the Marsh in 1925 with its controversial depiction of Niels Lindstedt's ill-fated marriage to a prostitute. But this was a special case: Pierce himself had seen the primitive conditions and frontier morality of Saskatchewan as a student teacher and minister between 1909 and I9I4, and Grove's compelling picture of that world had a special meaning for him. But he turned down E.J. Pratt's Witches' Brew in 1924 after having the vision to bring out Newfoundland Verse in 1923, and to 
his everlasting regret, lost Pratt forever from the Ryerson list. At the time, however, one can see in his diaries and letters his regret that Pratt's muse had taken to booze (Pierce attended only one of Pratt's famous stag parties - he had taken the pledge at age six and was repelled by the salacious stories). His own ideals and the fact that Ryerson was a church press prompted him to decline Pratt's book. He reluctantly told Pratt - who was ironically another son of Methodism - in October 1924:

Professor! How could you? Your Witches' Brew has been passed around the Book Room and both Dr. Fallis and the management generally have taken copious draughts from its sparkling rim. The general feeling is that a publishing house so closely connected with the Methodist Church could not very well act as Canadian distributor of it. ${ }^{34}$

A study of Pierce's correspondence shows that in the I940s he attempted to get poets like Patrick Anderson and A.J.M. Smith to drop poems he considered too sexually explicit or too graphic - for example Anderson's 'Dancer' and Smith's 'Ballade un peu banale.' 35 The sexual imagery of the poem 'Sublimation' - 'all unshirted my poppy wishes fall out' - made him ask Louis Dudek to delete it from East of the City (1946). ${ }^{36}$ Later, despite Pierce's interest in the work of Irving Layton; Pierce decided - to Layton's wrath - that The Improved Binoculars (1956), which incorporated such poetic images as 'the blood and balls of Christ' - was too indecorous for the Ryerson Press, as a division of the United Church Publishing House, to either publish or distribute. Pierce's scruples led Layton to publicly attack him as a relic of literary Victorianism. ${ }^{37}$

Pierce came to recognize the worth of the McGill poets and their successors, and to value their work as a 'social document' of the I940s and 1950s. While they never won his heart as Carman and Pickthall had, he realized around the time of the Second World War that the Ryerson list must include these 'new masters' as well as the 'old masters. ${ }^{38}$ Recognizing the effect of the Depression and the Second World War on the sensibilities of younger writers, he published the anthology Unit of Five (1944) which included the work of Louis Dudek, Raymond Souster, and P.K. Page. Pierce wrote of the anthology:

We [at Ryerson] were not impressed with the greatness of the book but we felt that this was what the world or the war had done to this 
generation of poets. Something rather dreadful has happened to our young writers and we submitted this not because we believed in it or thought it great art but as a document - a social document, if you will - of the time.... They are very young and very annoying and unripe, perhaps, but at any rate we submitted this book for what it was worth, not as a portent but as a sign for it had already taken place. $^{39}$

Pierce was determined that the Ryerson list continue to be a big gun - canonical, one might say! Privately, he tried to tone down some volumes, but publicly he insisted on the legitimacy of the Montreal school and their contemporaries:

We do not have to approve of it all, but we grant their freedom to speak out. Oftentimes, they are, like some of our contemporary artists, so thin and meaningless as to embarrass one. They will, having thought and suffered enough, grow up. Meanwhile it is all very exciting, their candour, their ribaldry and their prevailing disrespect. ${ }^{40}$

It would be misleading, however, to see Pierce as only reluctantly embracing all of the literature of the I940s and I950s. A.M. Klein's The Rocking Chair and Other Poems (I948) might have been written in the spirit of a reading of Pierce on bonne entente, and, when Ryerson brought out a second edition, Pierce proudly had the artist Thoreau MacDonald illustrate it. Pierce was a crucial early financial backer of John Sutherland's Northern Review. Sutherland told him he might have gone under without his help, ${ }^{4 \mathrm{I}}$ and in 1949 even offered him a collaboration: 'I suppose there is no chance of you yourself taking part in the editorship of Northern Review? It is an idea which appeals to me very much, and I think we could really make things move.'42

While Pierce was almost always driven by national ideals, his ideals of womanhood - which we have already seen operative in his remarks about Margot Asquith - were a factor in his editorial activities as well. Pierce could be very supportive of women writers, notably Annie Charlotte Dalton, Dorothy Livesay, and P.K. Page. In I95 I, at Livesay's suggestion, Pierce even had Ryerson finance child care so that she could work on literary projects. ${ }^{43}$ Nevertheless, one is struck by how frequently, during the first five decades of the twentieth century, the attitudes of critics (the overwhelming majority of whom were male) and editors (ditto) about traditional poetry 
and traditional images of femininity coalesce. Many of Pierce's dealings with women writers reflect this linkage. He is an important example of how the largely male literary establishment tended to stereotype Canadian women writers, a stereotyping which had marked results on both the careers of the individual women involved and the Canadian literary canon for the period. 44 The stereotyping reflected the uneasiness of a patriarchal, traditional literary establishment about the attributes of both poetic modernism and the modern woman, both of which were seen as tinged with sexual and social licence, hostility to tradition, and an unbecoming despair and alienation. Not surprisingly, male traditionalists were enthusiastic about female poets who seem to them to embody both romantic womanhood and romantic literature: that is to say, they were traditional, delicate, pure, refined, and non-threatening. This fusing of conservatism about both gender and literature by powerful literary men is especially instructive in regard to the careers of the poets Marjorie Pickthall (I883-1922) and Audrey Alexandra Brown (I $904-c .89$ ).

Some background is in order here, as in each case Lorne Pierce's dealings with these women are the chronological culmination of a pattern long evident in Pickthall and Brown's critical and publishing history. Throughout their careers, both women writers were consistently depicted by male critics as fragile, romantic, idealistic women, writing verse to which exactly the same adjectives were applied. During her lifetime, Pickthall's early career had been guided by critics Pelham Edgar and Andrew Macphail, the latter an outspoken foe of the new woman. ${ }^{45}$ Pickthall herself disliked the 'fragile poetess' stereotype of her, and once scornfully told a doting hostess who assumed that she would naturally admire a kindred spirit like Wordsworth's delicate Lucy Gray, that she would like to 'slap' Lucy Gray. ${ }^{46}$

One of Pierce's important projects in the I920s, and one that made his name, was his Marjorie Pickthall: A Book of Remembrance (I925), a reverential volume exquisitely bound in violet and gold cloth, which enshrines a literary and gender ideal of sweetness and sensitivity. To Pierce, Pickthall's work mirrored her nature. That is to say, in his eyes, both the woman (whom he had never known in life) and her work were beautiful, virtuous, and delicate as well as primarily emotional and intuitive, not intellectual or reasoned or systematic. As Joanna Russ has pointed out, much of the critical writing about women's work makes it apparent that the talent is perceived to emanate from an emotive 'nowhere and [it] bears no 
relation to anything. ${ }^{47}$ Pierce's analysis conforms to this pattern, and the conflation of the woman and her work is striking in Pierce's analysis:

The quality of her beauty is timeless. The total effect is a purifying and ennobling of the whole nature, and yet this is not reproduced by any doctrinal system of ideas, nor by reasoning of any kind, but, whatever, it is, produced through the imagination alone, an experience through which we are identified with the beautiful, which is not only felicitous, but also loving and true. ${ }^{48}$

In his diary for 18 April 1925 , Pierce wrote of Pickthall that '.. it is worth it all, even though I get nothing for it in a monetary sense, just to have dwelt so long with radiant beauty, and to have stood so near to the soul of sweet, simple goodness.' Pickthall's work, like her womanliness, was an exemplar of purity and refinement. $\mathrm{He}$ declared in the memorial volume: 'She is a challenge to bad artists dealing in cheap sentimentality, in muttering compromise and bad taste, and to all those who stress commonplace and subsidiary things ...'49 The reviews of the book tended to echo Pierce's views. The Toronto Globe review of the memorial volume commended Pierce's depiction of a 'shy, lonely girl. ${ }^{50}$ In the Canadian Bookman, Albert E. Smythe assured his readers that Pierce had respected Marjorie Pickthall's virtue - metaphorically of course:

Marjorie Pickthall might well have challenged the most prurient of [modern] biographers to do his worst and stood unscathed, for a purer soul has seldom been garmented in flesh. But Dr. Lorne Pierce has given a revelation of purity in a book that will stand among the classic biographies... ${ }^{5 \mathrm{I}}$

Some female readers were less taken with the stereotypical image of Pickthall evident in the volume. After reading the book, Helena Coleman, an older Toronto poet who had befriended Pickthall early in the century and who had given Pierce access to material and interviews about Pickthall, wrote letters to Pierce, protesting that, as she had told him when he was working on the volume, Marjorie was humorous and lively, not frail and drooping:

Altho' there was a good deal to contend with in [health] from time to time, she never gave the impression of sickliness - or even special delicacy of constitution. Her cheek was always rosy, her eye bright and lustrous. ${ }^{52}$ 
Ironically, Pierce himself had pointed out in A Book of Remembrance that Mariorie Pickthall had told a friend in I9I9 that 'To me the trying part is being a woman at all. ... As a man, [I] could go ahead and stir things up fine. 153 Nevertheless, Pierce and others portrayed Pickthall in the light of their own predilections and biases. In view of the widespread, primarily male, valorizing of her as a fragile feminine and literary ideal (and thus a 'romantic' figure in both life and art) - a valorization on which Pierce in all sincerity placed the posthumous capstone - it is ironic that when Pickthall entered a Victoria nursing home not long before her death suffering from depression, she was troubled by the sensation of a pressing 'weight on the top of her head.'54 As Sandra Gilbert puts it, 'though the pressures and oppressions of gender may be as invisible as air, they are also as inescapable as air, and, like the weight of air, they imperceptibly shape the forms and motions of [women's literary] lives. ${ }^{55}$

Patriarchal values also influenced Pierce's role in the career of poet Audrey Alexandra Brown. Born in British Columbia in 1904, Brown was a poet marginalized by four factors: her gender, her poverty, her crippling arthritis, and her distance from Eastern publishers (she was not to travel outside British Columbia until she was over forty and was never able to visit her centres of publication in Toronto, Ottawa, and Montreal because of lack of funds). ${ }^{56}$ In the late I920s, Brown's poetry was 'discovered' and eagerly taken up by critics like Lorne Pierce, Pelham Edgar, Sir Andrew Macphail, and B.K. Sandwell, all of whom admired its Keatsian flavour in the face of the austerities of modernism. A Dryad in Nanaimo, her first volume, was published by Macmillan in I93 I. Again an ideal of femininity was operative, and Brown was stage-managed much more than a young male poet would have been. She frequently suffered the denial of agency so commonly the fate of women writers. ${ }^{57}$ For example, Edgar picked all the poems for her first book largely without consulting her, and, being a notoriously bad correspondent, rarely kept her informed of developments in a timely or consistent way. ${ }^{58}$ Her publicity, engineered by Edgar, Sandwell and others, presented her as the fragile, maidenly, invalid girl-poet. The representation of her as a reassuringly old-fashioned poet and old-fashioned girl might best be summed up by a scornful remark made by Duncan Campbell Scott to Pelham Edgar in 1938 that she ought to receive some government financial support since the small sum Brown desired "would not keep one of the "up-do-date" poetesses in cigarettes. ${ }^{59}$ Both her poetry and her person were seen as embody- 
ing maidenly virtues of refinement, purity, and delicacy — qualities antithetical to the perceived sexual frankness and cynicism of both poetic modernism and the modern woman, as Scott's remark suggests. Both the woman and her work were seen as undefiled and unpolluted by the modern world, and the 'poetess' in need of chivalrous patronage and guidance. Given such thinking on the part of prominent men of letters, it is not surprising that when Pelham Edgar wrote a preface to the I934 edition of $A$ Dryad in Nanaimo, one defending a Brown poem like 'Laodamia' against modernist critics, he used imagery of assault which suggested rape: 'But even the ultramodernist must refrain from laying violent hands on Laodamia. ${ }^{160}$

By the late 1930s, it had become evident to Edgar and others that Brown's poetry was not going to develop as they had hoped to challenge modernism by means of a more traditional, romantic mode. Brown's letters to Edgar (described in the press as her 'fairy godfather ${ }^{16 \mathrm{I}}$, now at the E.J. Pratt Library of Victoria University in Toronto, betray her frustration at her isolation and dependency, as the interest of her lordly eastern admirers waned.

In 1946, Pierce, who had helped Brown financially through the Canadian Writers' Foundation, took over her career (he had earlier jokingly asked another Brown admirer if the young lady was 'attached, and, if not, would she entertain a proposition' for publication ${ }^{62}$, , hoping to stimulate flagging sales, first with a Macmillan volume, then with Ryerson. ${ }^{63}$ Although he deplored the marketing of Brown as the invalid poet, he too assumed a take-charge stance. Pierce and Edgar had earlier made the choice of poems for The Tree of Resurrection (1937) without her final approval. When Brown moved to Ryerson, Pierce told her: ' . . . it is I who shall be taking the lead [in managing your career] and not Dr. Edgar or anyone else. ${ }^{64}$ Given all these literary overseers, it is perhaps suggestive that in one letter to Pierce, Brown's signature is cramped into a tiny corner of the page. ${ }^{65}$ In another letter, she told Pierce that: 'I want you to know that you have my completest confidence always, and that you may count beforehand on my approval of whatever you may think best. ${ }^{166}$ When the reviews and sales for All Fool's Day (I948) were both dismal, Brown secretly took a typing and shorthand course and got a job as 'girl friday' at a radio repair shop. ${ }^{67} \mathrm{Her}$ subsequent letter to Pierce shows the burden of gender in women's occupational roles: 'Dear Lorne, being employed is such fun! ... If any of my work was truly good, it will survive: if not, then it's only right it should perish. My ego is bolstered by the thought that though I've failed as a poet I've succeeded as a secretary! ${ }^{68}$ 
Pierce was more constant than Pelham Edgar. The flagging of Brown's career did not prompt him to let lapse his efforts to help Brown financially and professionally. But Brown's decline in sales and reputation contributed to a diminution of his faith in the preeminence of romantic poetic modes. In 1955, he wrote wearily to the secretary of the Canadian Writers' Foundation: 'Audrey Brown was also a protege of Pelham's. ... She soared up into the blue, and we all thought she was headed for immortal things. But her style of lyric, like Carman's, is dated, while her preoccupation with death and such is tiresome. ${ }^{69}$ Such feelings prompted Pierce to judge the work of poets like Brown, Bliss Carman, and Wilson MacDonald more stringently. ${ }^{70}$ Moreover, from the mid-I 940 , Pierce turned Ryerson increasingly to the publication of such poets as A.J.M. Smith and F.R. Scott, whose work, as we have seen, he found of importance to the country though personally uncongenial to his literary idealism.

Clearly, therefore, the policies of Canada's most influential twentieth-century editor were shaped by ideals of nationality, morality, and gender in the context of his times. Pierce read and criticized literary manuscripts as well as publishing them, and his dynamism gives his ideas resonance in the cultural record. Given Lorne Pierce's prodigious labours in literary vineyards - as he said 'pounding away with that utter dedication Methodism bestows upon all her sons ${ }^{71}$ - the contours of an important part of the Canadian literary canon for the period 1920 to 1960 must be seen in the light of the patriotic, moral, and patriarchal values of this major literary tastemaker.

\section{RÉSUMÉ}

La carrière de Lorne Pierce (1890-1961), éditeur de Ryerson Press de 1920 à 1960, fut marquée par ses valeurs morales, nationalistes et patriarcales. Étant donné le rôle important joué par Pierce dans le monde littéraire canadien, ses valeurs ont eu un impact immense sur la formation d'une norme littéraire canadienne.

Le nationalisme de Pierce a d'abord été influencé par son éducation méthodiste et sa formation de pasteur, et par ses études à Queen's University (B.A., I9I3) où il est entré en contact avec l'héritage nationaliste de George Monro Grant. En conséquence, Pierce concevait la littérature canadienne comme une force patriotique pour la cohésion nationale. Son nationalisme littéraire se 
situe derrière les jalons laissés par la collection de Ryerson, «Makers of Canadian Literature,» dans les années I920, une collection qui mettait l'emphase sur la création d'un intellectualisme de nation et sur le besoin d'une entente culturelle entre francophones et anglophones. Le nationalisme culturel de Pierce est à la base des efforts de publication de Ryerson Press dans le domaine de l'art canadien et de l'histoire de l'art, et de sa propre rédaction de la très réussie collection The Canada Books of Prose and Verse, collection de livres de lecture pour écoles élémentaires et secondaires qui ont dominé le marché du manuel scolaire de langue anglaise entre les années I930 et I960.

Les valeurs morales rigoureuses de Pierce, alliées à sa surdité et son intellectualisme, ont fait de lui une figure unique dans le monde canadien de l'édition de son époque. Par exemple, il fut un éditeur à l'influence intellectuelle plus grande qu'aucun autre des éditeurs nationalistes contemporains comme Hugh Eayrs de Macmillan of Canada, ou John McClelland de McClelland and Stewart. Son moralisme, allié au fait que Ryerson Press était une subdivision de Methodist Book and Publishing House (The United Church Publishing House à partir de 1925) a influencé la liste de publications de Ryerson. Par exemple, c'est ce même moralisme qui l'a conduit à son refus de publier The Witches' Brew de E.J. Pratt (I925) à cause des divertissements alcooliques contenus dans le livre. Lorsque Pierce commença à publier les poètes de l'école McGill et leurs successeurs dans les années I940, tels A.J.M. Smith et Louis Dudek, il leur demandait souvent de supprimer des passages qu'il jugeait offensants pour la morale.

Le comportement patriarcal de Lorne Pierce fait de lui un exemple parfait de la tendance qu'avait l'intelligentsia littéraire canadienne, majoritairement masculine, de la période de 1920 à I960, à promouvoir les auteurs féminins qu'elle voyait comme incarnant les idéaux littéraires féminins de pureté, tradionnalisme, raffinement et délicatesse. Une telle promotion fut encouragée par une réaction à leur perception de la nature du modernisme poétique et de la femme moderne, dont la liberté sociale et sexuelle et l'hostilité à toute convention dérangeaient. Cette liaison entre le genre féminin et le genre littéraire est illustré par l'implication de Pierce dans la carrière et la réputation de poètes comme Marjorie Pickthall (1883-1922) et Audrey Alexandra Brown (1904-c.89). 


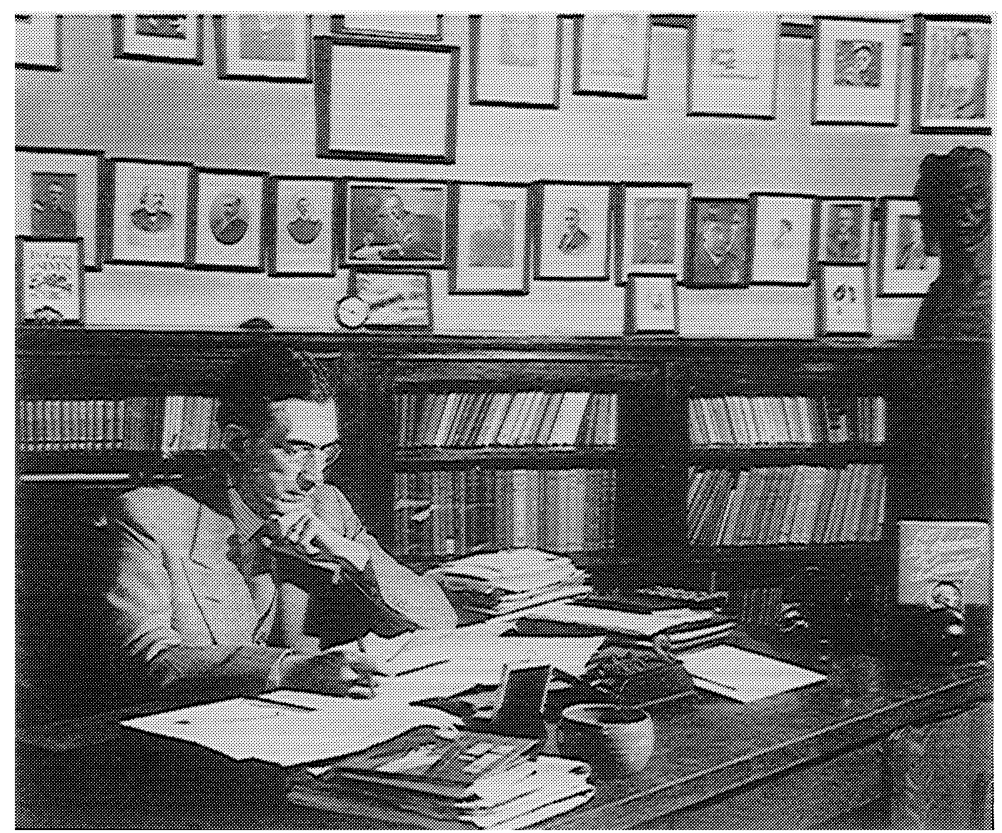

I. Lorne Pierce in his Ryerson Press office, c. 1948

- hearing aid in place, with his canon of

books and photographs arrayed behind him.

Lorne Pierce Scrapbook, box 65, p. I 9I.

(Courtesy of the Queen's University Archives.) 


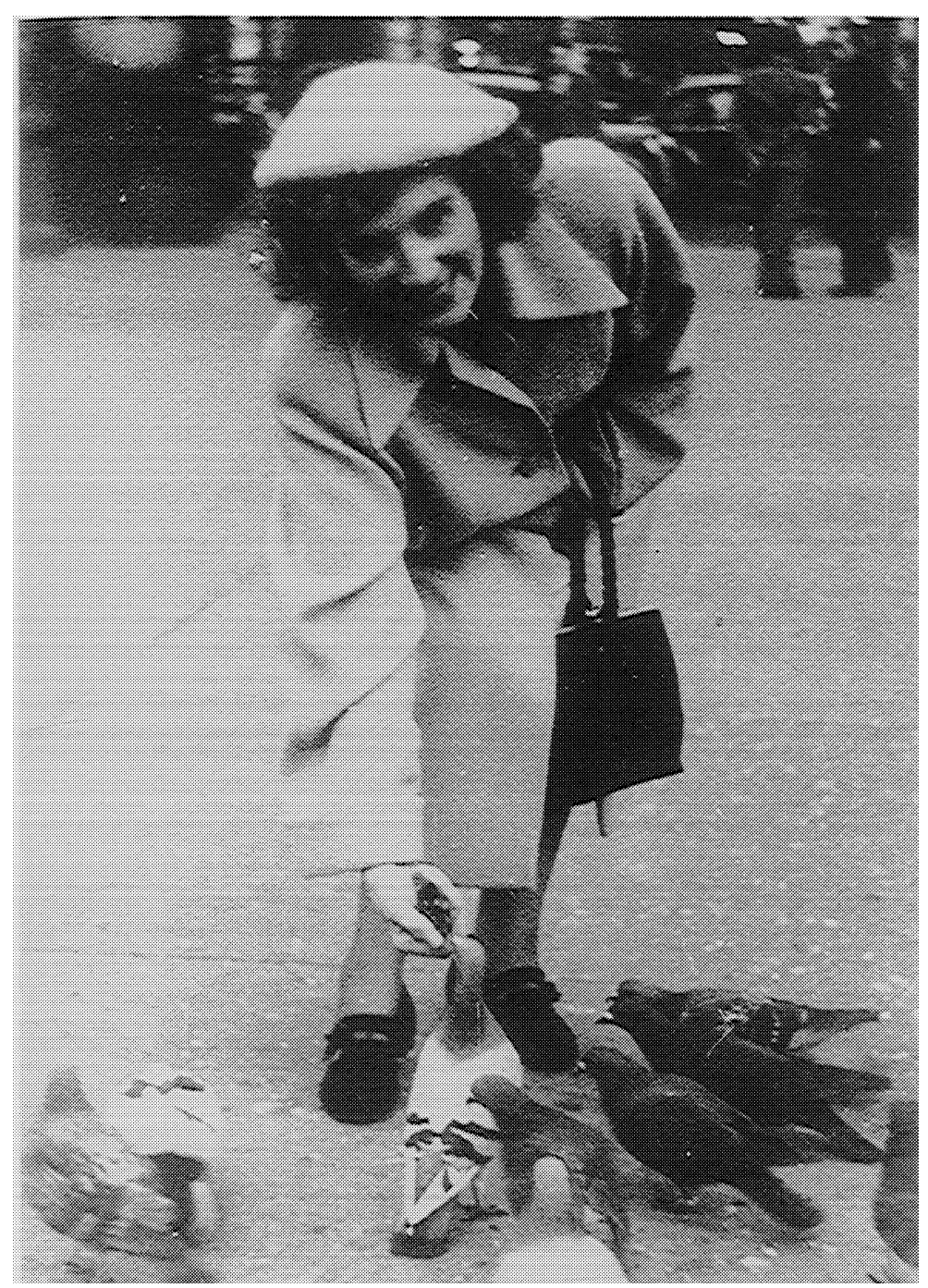

2. Poet Audrey Alexandra Brown, 1950.

Lorne Pierce Scrapbook, box 65, p. 39.

(Courtesy of the Queen's University Archives.) 


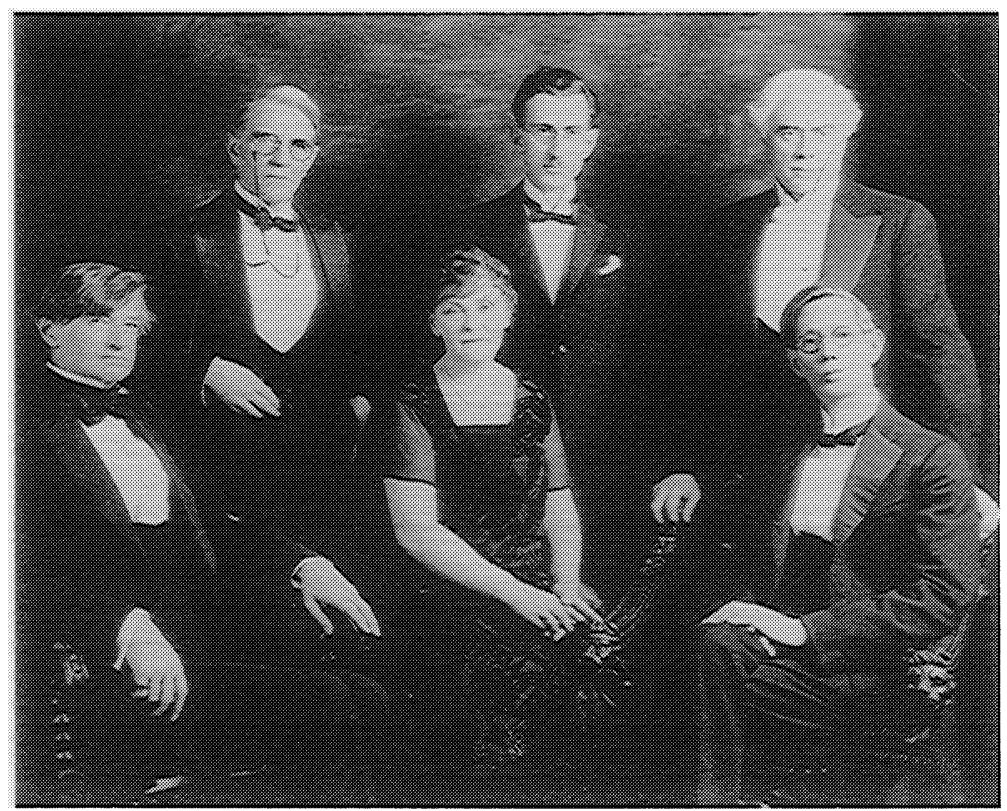

3. Vancouver 1927 , literary idealists all: (seated, left to right) Bliss Carman, Annie Charlotte Dalton, A.M. Stephen; (standing, left to right) Charles G.D. Roberts, Lorne Pierce, Dr. Ernest Fewster. File I 3, box 2, Blanche Hume Papers.

(Courtesy of the Queen's University Archives.) 


\section{NOTES}

My work on a biography of Lorne Pierce is supported by a research grant from the Social Sciences and Humanities Research Council of Canada. My thanks to Beth Robinson, daughter of Lorne Pierce, for kind permission to use manuscript material and to Mrs. Robinson, John Webster Grant, H. Pearson Gundy, C.H. Dickinson, Marshall Laverty, and William F.E. Morley for interviews and research material. Particular thanks to the staff of Queen's University Archives, who make research in their collections a delight. I also wish to thank Duncan McDowall, Lorraine McMullen, Mary Vipond, and the journal's two anonymous referees for their helpful comments.

For an outline of Pierce's career, see C.H. Dickinson, Lorne Pierce: A Profile (Toronto: Ryerson, 1965).

For a discussion of the literary nationalism of Canadian critics, see Margery Fee, 'English-Canadian Literary Criticism, I890-1950: Defining and Establishing a National Literature' (Ph.D. diss., University of Toronto, 198I) and Carl Ballstadt, ed., The Search for English-Canadian Literature (Toronto: University of Toronto Press, 1975). Fee's stimulating discussions of Pierce's career as critic and editor focus primarily on Pierce as romantic nationalist in literary-historical terms, but, to my mind, his Methodist upbringing and ministerial education and career merit examination as the dominant influence on his thinking.

For a discussion of John McClelland and the history of McClelland and Stewart, see George Parker, The Beginnings of the Book Trade in Canada (Toronto: University of Toronto Press, 1985), 236-8, 250, and his 'A History of a Canadian Publishing House: A Study of the Relation Between Publishing and the Profession of Writing I 890-I940' (Ph.D. diss., University of Toronto, 1969). See also Carl Spadoni and Judy Donnelly, A Bibliography of McClelland and Stewart Imprints, 1909-1985: A Publisher's Legacy (Toronto: ECW Press, 1994), 19-53. The cultural nationalism of Eayrs is discussed in Mary Vipond, 'National Consciousness in English-Speaking Canada in the 1920s' (Ph.D. diss., University of Toronto, 1974) and by Danielle Hamelin, 'Shaping the Canadian Reading Public: The Macmillan Company of Canada, 1906-192 I' (paper presented at the annual meeting of the Canadian Historical Association, Carleton University, June 1993).

Pierce was profoundly deaf by the end of the I920s, a hearing loss that was already acute at the time of his arrival at Ryerson in I920. From the I920s, with the help of his wife, Edith Chown Pierce, his secretary, Blanche Hume, and subsequently his daughter, Beth Pierce Robinson, and his son, Bruce Pierce, as well as the use of primitive hearing aids like the Acousticon and some lip reading, Pierce overcame his handicap to a large degree. He could not really use the telephone, and as a result his correspondence is voluminous. A founder in the I940s of what is now the Canadian Hearing Society, he was acutely aware of the isolation and challenges his deafness created in his business and family life. Pierce found interaction at large gatherings particularly trying, and it was difficult for him to give public lectures and addresses because of his deafness. 
One only has to realize how important 'networking' and socializing are to an editor or publisher to realize the challenge the deafness posed and the remarkable measure of Pierce's success in meeting the challenge with the help of his colleagues and family. For comments on Pierce's deafness and the difficulties it brought in his career, see Dickinson, Lorne Pierce, 66, as well as E.K. Brown to Duncan Campbell Scott, 13 June 1944, in R.L. McDougall, ed., The Poet and the Critic: A Literary Correspondence between D.C. Scott and E.K. Brown (Ottawa: Carleton University Press, 1983), I09.

5 For a discussion of the Methodist Book and Publishing House, and its successor from 1925, the United Church Publishing House, see Parker, The Beginnings of the Book Trade, 123-4, 208-10, and 237-8, and Janet Friskney, 'Towards a Canadian "Cultural Mecca": The Methodist Book and Publishing House's Pursuit of Book Publishing and Commitment to Canadian Writing 1829-1926' (Master's thesis, Trent University, I994).

6 'Lorne Pierce,' Liberty, 20 September 1947, 17.

7 Fallis was himself a recent appointee to the Methodist Book and Publishing House, one who had little knowledge of publishing but a firm resolve to 'beef up' the Methodist Book and Publishing House's publication programmes, both within and without the Methodist Church. By 1920, Pierce was already establishing a reputation within the Methodist Church of Canada as a dynamic, young minister with both literary and social gospel interests. Fallis's attendance at the June 1920 Montreal Conference, where Pierce caused a sensation by a lecture on the spiritual idealism of Russian literature (a topic made controversial by the events of the Russian revolution and Pierce's optimistic hopes for its cultural and social possibilities/ confirmed the Book Steward's interest in recruiting Pierce as Literary Critic and Advisor. Interestingly, Fallis initially saw Pierce's role as primarily focused on stimulating book sales and book programmes for and by Canadian Methodist ministers, for example by ghost-writing 'The Book Steward's Corner,' a review column in the Methodist Church's weekly Christian Guardian.

8 Lorne Pierce Diary, I 8 June and I I July 1920, Lorne Pierce Papers, Queen's University Archives, Kingston, Ont. Unless otherwise indicated, all references to archival material are to the Lorne Pierce Papers, Queen's University Archives.

9 Lorne Pierce, interview with Ronald Hambleton, undated [1950s], file I I, box 42.

Io Pierce entered the B.D. programme at Victoria College in I9I4, having earned a Queen's B.A. in I9 I 2 (though the degree is actually dated I9 I3). While at Queen's he spent summers near Moose Jaw as a teacher, and was a probationary minister of the Methodist Church in Saskatchewan before his arrival at Victoria in September 1914. Invalided out after one term, he transferred to Union Theological Seminary, New York City, in 1915-16. With courses at New York University, he received a Union B.D. (I9I6) and a New York University M.A. (I9I6) as well as an ad eundem B.A. from Victoria in 1917. He received an S.T.D. (i.e. a doctorate in theology/ from United Theological College in Montreal in 1922, done externally.

I I Lorne Pierce, 'The Gods of This New Era,' Canadian Magazine, February I9 I8, 279-84. 
I2 Pierce to Rev. Garth Legg, undated [1958], file 4, box 27.

13 Pierce was born in 1890 in the eastern Ontario village of Delta. His parents, Harriet and Edward Pierce, were devout Methodists, particularly his mother, a temperance activist. The childhood journal kept by his mother about young Lorne in the possession of Beth Pierce Robinson records that Pierce's first words were 'Mother' and 'Jesus,' and that his mother, who steered him toward the ministry from the cradle, had him lisping mock sermons at eighteen months, and signing the temperance pledge at age six.

I4 See William Westfall, Two Worlds: The Protestant Culture of NineteenthCentury Ontario (Kingston: McGill-Queen's, 1989), 195.

I5 Pierce, 'Canadian Literature and the National Ideal,' Canadian Bookman 7 (September 1925): 143-4.

I6 For a study of the work of William Briggs and his editors, see Friskney, 'Towards a Canadian "Cultural Mecca."'

17 Pierce and Albert Durrant Watson, eds., Our Canadian Literature: Representative Prose and Verse (Toronto: Ryerson, 1922), 124-5.

18 The nationalism of George Monro Grant, Principal of Queen's from 1877 to 1902, was still potent during Pierce's undergraduate years at Queen's (1909-12). So impressed was Pierce by Grant's urging of French-English amity and mutual understanding that he later chose to reprint a selection from Grant's writing on the subject in one of Ryerson's widely successful school readers. See George Monro Grant, 'Canada - A Link in the Empire,' in Our Heritage, ed. C.T. Fyfe and Lorne Pierce (Toronto: Ryerson and Macmillan, I948), 5 I 5.

I9 Pierce, Towards the Bonne Entente (Toronto: Ryerson, I929), 23-4.

20 For another discussion of the series, see Margery Fee, 'Lorne Pierce, Ryerson Press, and The Makers of Canadian Literature Series,' Papers of the Bibliographical Society of Canada 24 (I985): 5 I-7 I.

2I Watson to Pierce, 6 September I924, file I I, box I.

22 Macphail to Pierce, 9 November 1923, file 5, box 1 .

23 Pierce to Macphail, 8 February 1924 , file 9, box I.

24 Macphail was still crisp in his revised text of 'Norman Duncan: An Estimate,' for example: '[Duncan's] passion for the mechanical reproduction of vernacular drives him far beyond the limits of literary taste ...' (p. I6); and 'The truth is Norman Duncan never completely achieved a general style of his own, his own way of saying things' (p. 24). See 'Norman Duncan' file, vol. 5, Macphail Papers, National Archives of Canada.

25 Macphail to Pierce, 26 February 1924, file 9, box I.

26 Pierce, An Editor's Creed (Toronto: Ryerson, 1960), 7.

27 Pierce to D.I. McLeod, 30 October 1939, file 6, box 7.

28 John Webster Grant, Report of the Book Editor to the Board of Publication, April I96I, file I7, box 45 .

29 Pierce to Sir Charles G.D. Roberts, 20 October I94I, file 5, box 8. Pierce often stresses in the correspondence that poetry perpetually lost money for Ryerson.

30 Pierce, An Outline of Canadian Literature (Toronto: Ryerson, 1927), 240.

3I Albert H. Robson, Rous and Mann Ltd., to Pierce, 2 I April I937, file ro, box 6.

32 Pierce, In Conference with the Best Minds (Nashville: Cokesbury, 1927), 232. 
The material had earlier appeared in the Christian Guardian.

33 Pierce, review of An Intimate Diary, by Margot Asquith, Christian Guardian, 20 October 1920, 25.

34 Pierce to Pratt, 16 December 1924, file Io, box I.

35 See A.J.M. Smith to Pierce, 29 June 1943, file 3, box 10, and Frank Flemington to Patrick Anderson, 19 April 1946, file 5, box 13.

36 Pierce to Louis Dudek, 1o June 1946, file 6, box I 3 . In his reply of 14 June, Dudek agreed to the deletions.

37 See Irving Layton to Pierce, 22 December 1956, file 5, box 25. Layton's public criticisms are described in 'Poet Attacks Publisher's Attitude,' Globe and Mail, I 4 January I957, Scrapbook 67 A.

38 Pierce to Smith, 28 November 1944, file 4, box Ir.

39 Pierce to Livesay, 25 April 1945 , file 5, box 12 . She had reviewed Unit of Five.

40 Pierce, A Canadian Nation (Toronto: Ryerson, 1960), 28.

4I John Sutherland to Pierce, I4 November I95 I, file I2, box 20, published in The Letters of John Sutherland, I942-1956, ed. Bruce Whiteman (Toronto: ECW Press, 1992), 219-20.

42 Sutherland to Pierce, 15 December 1950 , file 6, box 18 , published in The Letters of John Sutherland, 1942-1956, 100.

43 See Dorothy Livesay to Pierce, 27 February 195 I, file 8, box 20.

44 Carole Gerson does an instructive, quantitative analysis of the under-representation of Canadian women writers in the important anthologies, including Pierce and Watson's Our Canadian Literature, thus revealing another aspect of the effect of patriarchal values on the canon. See Gerson, 'Anthologies and the Canon of Early Canadian Women Writers,' in Re(Dis)Covering Our Foremothers: Nineteenth-Century Canadian Women Writers, ed. Lorraine McMullen (Ottawa: University of Ottawa Press, I988), 55-76.

45 Edgar and Macphail wrote to each other in a congratulatory vein about their guidance of Brown and 'our Marjorie.' Edgar smugly reminded Macphail that 'I score over you by at least two years in the matter of Miss Audrey Alexandra Brown ...' Macphail to Edgar, 2 October [1930], vol. 3, Macphail Papers.

46 The story is related in Jean Blewett, clipping from [Saturday Night], 9 May 1925, Scrapbook 52.

47 Joanna Russ, 'Anomalousness,' in Feminisms: An Anthology of Literary Theory and Criticism, ed. Robyn R. Warhol and Diane Price Herndl (New Jersey: Rutgers University Press, 1991), 197.

48 Pierce, Mariorie Pickthall: A Book of Remembrance (Toronto: Ryerson, 1925), Io6.

49 Ibid., 197.

50 'True Poet and Canadian,' Toronto Globe, 23 April 1925, Scrapbook 52.

5 I Albert E. Smythe, 'Marjorie Pickthall,' Canadian Bookman, May I925, Scrapbook 52 .

52 Helena Coleman to Pierce, 7 March 1925 , file I, box 2. She had stressed this to Pierce before the biography was published in Coleman to Pierce, 24 July 1924, file 7 , box $\mathrm{I}$.

53 Pickthall, quoted in Pierce, Marjorie Pickthall: A Book of Remembrance, ro4. 
54 Charles Mair to Pierce, I5 October 1925, file 2, box 2.

55 Sandra M. Gilbert, 'What Do Feminist Critics Want?' in The New Feminist Criticism: Essays on Women, Literature and Theory, ed. Elaine Showalter (New York: Pantheon, 1985), 33.

56 Audrey Alexandra Brown to Pierce, 3 February 1948, file 3, box 17.

57 See Russ, 'Anomalousness,' for a discussion of denial of agency as one of the factors tending to marginalize women writers.

58 For an examination of Edgar's relations with Brown and Pickthall, see Sandra Campbell, 'The Canadian Literary Career of Professor Pelham Edgar,' (Ph.D. diss., University of Ottawa, I983).

59 D.C. Scott to Edgar, I5 April 1938, Edgar Papers, E.J. Pratt Library, Victoria University. The reference is to a small monthly allowance from the B.C. government.

60 Pelham Edgar, 'Preface' to Brown, A Dryad in Nanaimo, rev. ed. (Toronto: Macmillan, 1934), v. Note the similarity to Smythe's imagery in the latter's review of Pierce's Pickthall volume quoted above.

6I Jean Graham, 'Among Those Present, A Sweet Singer Lxxiv - Audrey Alexandra Brown,' Saturday Night, 23 July I933, 8.

62 Pierce to Macphail, 5 November 1930, vol. 3, Macphail Papers.

63 Sales figures in the Macmillan records for Brown's books indicate that the first edition of $A$ Dryad in Nanaimo (I93 I) sold I,605 copies, a very good sales figure for a book of poetry, especially during the Depression. By contrast the 1936 Macmillan poetry anthology New Provinces sold less than roo copies. Brown's 1944 book Challenge to Time and Death sold 473 copies. Macmillan Company of Canada Archives, William Ready Division of Archives and Research Collection, McMaster University Library.

64 Pierce to Brown, 24 January 1948 , file 3, box 17.

65 Brown to Pierce, 2 I May I947, file 6, box I4. Brown was responding to a letter in which Pierce had told her that her themes of loss and death had little appeal to the public. She was obviously shaken by the comments, but she concludes: 'Your letters are the greatest pleasure to me.' What strikes the eye is that the much tinier ' $m e^{\prime}$ and the signature 'Yours, Audrey Alexandra Brown' are cramped and crooked in the corner of the letter in marked contrast to her usual penmanship.

66 Brown to Pierce, 3 February I 948 , file 3, box 17.

67 Pierce to Eugenie Perry, 24 January I 949 , file 5, box I 8 , and Brown to Pierce, I November 1953 , file 2, box 22, discuss the poor reviews and the fact that 500 copies could not even be sold as remainders.

68 Brown to Pierce, I I September 1955, file I, box 23. Ironically modernist women writers like Phyllis Webb, P.K. Page, and others often fared no better within the confines of Canadian modernism, where sexual exploitation was sometimes added to sexism. See, for example, Lorna Knight, "'With all best wishes, high hopes and thanks": Phyllis. Webb, Canadian Poetry, and Publishing in the Early I950s,' West Coast Line (winter I99 I-92): 43-53.

69 Lorne Pierce to Teresa Thomson, 2 I February 1955, vol. 8, Canadian Writers' Foundation Papers, National Archives of Canada. To his credit, Pierce, unlike 
some other former admirers of Brown, supported the continuation of Brown's small pension despite her now-smaller literary output. I wish to thank the C.W.F. for permission to consult this material.

70 For example, Pierce has been severely criticized for his editorial revisions of Carman's poems in his edition of The Selected Poems of Bliss Carman (Toronto: McClelland and Stewart, 1954). Pierce's editorial judgement, however, was prompted by his belief as Carman's literary executor that Carman, whose reputation was in eclipse by the 1950 , had to be presented in a manner more congenial to changing literary tastes if he was to retain canonical significance. Once again, Pierce was driven by cultural nationalism. For mention of the Carman volume, see John R. Sorfleet, 'On Analyzing and Editing Bliss Carman's Work: The Critical Question,' in Bliss Carman: A Reappraisal, ed. Gerald Lynch (Ottawa: University of Ottawa Press, I990), 53-60.

7 I Pierce to Rev. Marshall Laverty, 4 August 1956, courtesy of Rev. Laverty. 